\title{
Statistical Machine Translation Muna To Indonesia Language
}

\author{
Quranul Alfahrezi Agigi*1, Arie Ardiyanti Suryani ${ }^{2}$ \\ ${ }^{1,2}$ Telkom University; Jl. Telekomunikasi No. 1, Terusan Buahbatu - Bojongsoang, \\ (022) 7564108 \\ ${ }^{3}$ Jurusan Informatika, Fakultas Informatika Universitas Telkom, Bandung \\ e-mail: *11 quranulalfahrezi@student.telkomuniversity.ac.id, ${ }^{2}$ ardiyanti@telkomuniversity.ac.id
}

\begin{abstract}
Abstrak
Pada perkembangan teknologi yang pesat ini, masih sedikitnya ditemukan mesin penerjemah dari Bahasa daerah ke Bahasa indonesia. Maka dari itu, Paper ini membahas tentang pembuatan mesin penerjemah statistik bahasa Muna ke bahasa Indonesia karena masih sedikitnya didapatkan mesin penerjemahan Bahasa Muna ke Bahasa indonesia. Pendekatan yang digunakan berbasis statistik menggunakan corpus parallel. Pada penelitian ini, data yang diambil berasal dari buku berjudul Cerita Rakyat Buton Dan Muna di Sulawesi Tenggara dan beberapa artikel-artikel cerita rakyat yang ada di internet. Jumlah corpus parallel yang digunakan sebanyak 1050 baris kalimat dan corpus monolingual sebanyak 1351 baris kalimat. Adapun skenario yang akan dilakukan pada percobaan ini terbagi atas dua skenario. Skenario 1 adalah pengujian pada corpus parallel (training) yang diuji menggunakan baris kalimat yang tersedia dan baris kalimat tersebut akan ditambahkan pada setiap percobaan, sedangkan sisa dari baris kalimat yang dimiliki akan digunakan pada corpus parallel (testing). Pada skenario 2, pengujian dilakukan dengan melakukan perbandingan baris kalimat corpus monolingual setelah melakukan pengurangan dan penambahan baris kalimat. Agar skenario 2 berjalanan, dibutuhkan akurasi pada skenario 1 yang paling terbaik. Pengujian dilakukan sebanyak 6 kali menggunakan tools BLEU (Bilingual Evaluation Understudy). Dari hasil pengujian yang dilakukan mendapatkan nilai akurasi terbaik yaitu sebesar 29,83\%.
\end{abstract}

Kata kunci-Mesin Penerjemah Statistik, corpus parallel, corpus monolingual, BLEU

\begin{abstract}
In this rapid technological development, there are still at least some machine translators from regional languages to Indonesian. Therefore, this paper discusses to make a statistical translation machine for the Muna language into Indonesian because at least there are still at least a Muna translation machine into Indonesian. The approach used a statistically based using parallel corpus. In this study, the data taken came from a book entitled Folklore of Buton and Muna in Southeast Sulawesi and several folklore articles on the internet. The number of parallel corpus used is 1050 sentence lines and the monolingual corpus is 1351 sentence lines. The scenarios that will be carried out in this experiment are divided into two scenarios. Scenario 1 is testing on the parallel corpus (training) which is tested using the available sentence lines and these sentence lines will be added to each experiment, while the rest of the sentence lines that are owned will be used in the parallel corpus (testing). In scenario 2, the test is carried out by comparing the lines of the monolingual corpus sentences after subtracting and adding sentences. In order for scenario 2 to run, accuracy is needed in scenario 1 which is the best. The test was carried out 6 times using BLEU (Bilingual Evaluation Understudy) tools. From the results of the tests carried out, the best accuracy value is $29.83 \%$.
\end{abstract}

Keywords - Statistical Machine Traslation, parallel corpus, monolingual corpus, BLEU 


\section{BACKGROUD}

I anguage is used to communicate with each other between individuals which contains ideas, ideas, concepts or feelings to others. Language used as a tool for socializing and social adaptation between humans with one another so that their lives get an important insight. Nowadays, there are various languages from various regions that are only known in the area, one of which is the Muna language. Muna is an Austronesian language spoken mainly in the western part of Muna Island and Buton Island in the southeastern part of Sulawesi [1]. This language is one of the endangered languages in the world and the number of its speakers is decreasing every year [2].

This makes it difficult to communicate between regions. Informatics can play a role which help to solve these problems by processing the existing language using computer assistance so that it can be understood by people in various regions. In order to be implemented, the Natural Language Processing (NLP) science domain is needed.

Machine Translation (MT) is one of the applications of NLP. MT for European languages has been widely used as a solution to problems in communicating between European languages. However, regional languages in Indonesia are still lacking. Therefore, the Statistical Translator Machine (MPS) can translate Indonesian into regional languages with the aim of facilitating communication between regions.

Statistical Machine Translation (MPS) is a machine translation model in which translations are generated according to statistical models generated from parallel corpus analysis. A corpus is defined as a collection of examples of written text or spoken language where data types can provide records as machine-readable linguistic information [3].

Nowadays, there are not many statistical translation machines for Indonesian-Local Languages. Research on machine translation of regional languages with Indonesian has been carried out by several researchers, including the MPS study using the phrase-based statistical method which obtained an accuracy value of $44.02 \%$ for Indonesia-Java and $58.77 \%$ for JavaIndonesia [4]. In addition, there is a study using the Pivot Language method on the English to Sambas Malay translator machine which has an accuracy rate of $20.854 \%$ [5]. As for other studies that use the Pos Tag method for Sundanese to Indonesian where the number of parallel corpus greatly affects statistical machine translation. The author also explains that there are several obstacles faced in this experiment, namely there are many OOVs and incorrect translation of phrases caused by the lack of parallel corpus and there are typos in the creation of the Sundanese corpus [6].

For now, there is still no machine translator for Muna - Indonesian. Currently, the only resources that can be used are online dictionaries on the internet. In accordance with the case study, in order to avoid the extinction of local languages, a statistical translation machine for Muna - Indonesian was made.

The problems discussed in this paper are whether statistical machine translation can be implemented in Muna Language - Indonesian and what are the results of statistical machine translation testing in Muna - Indonesian. The problem limitation of this paper is that this statistical machine translator only translates in one direction, namely Muna Language as the source language and Indonesian as the target language. The purpose of this research is to be able to make a statistical translation machine for Muna - Indonesian and with a fairly good accuracy. 


\section{RESEARCH METHOD}

\subsection{Literature Review}

\section{1.1 Statistical Traslation Engine}

Statistical machine translation (MPS) or statistical machine translation (SMT) is a machine translation model in which machine translation is performed according to a statistical model with parameters obtained from corpus analysis [7]. Statistical machine translation (SMT) has three components that participate in the process of translating sentences from one language to another: language model, translation model, and decoder [8].

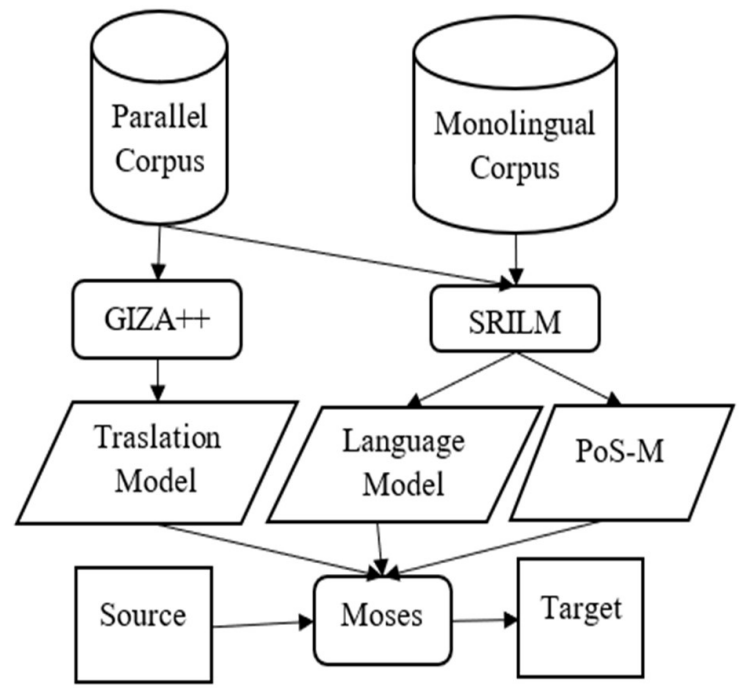

Figure 1 Architecture of The Moses Statistical Machine Translator [9].

Figure 1 is the system architecture of the Moses statistical machine translator, there are two training processes in statistical-based machine translation, namely training the translation model and training the language model. Training model translation with parallel corpus using GIZA++, translation model (MT) is generated. Using SRILM for language model training with a monolingual corpus combined with a single target language creates a language model (LM). On the other hand, the PoS model (Pos-M) is generated from the parallel corpus target language, and each word is marked with PoS. The Moses decoder was built using TM, LM, and PoS-M. Moses is also used as an automatic translator to generate the target language from the source language input text [10].

\section{1.2 Moses}

Moses is an open-source tool implemented in a statistical machine translator. When translating languages, Moses needed two languages: the source language and the target language [11]. Moses is available as Windows and Linux source code as well as binary distributed under the Lesser General Public License (LGPL). Its development is supported by the Euro Matrix project. With financial support from the European Commission [12]. 


\section{1.3 Corpus}

Corpus is defined as a collection of examples of written or spoken text in the form of data that can be recorded as various linguistic information that can be read by a set of machines [13]. The corpus can be classified into eight types of corpuses, namely specialized corpus, general corpus, comparative corpus, parallel corpus, historical or diachronic corpus, and monitor corpus. (Monitor corpus) [14].

\section{1.3 Automatic Evaluation}

BLUE (Bilingual Evaluation Understudy) is an automatic evaluation metric where the way this method works is to compare the output of a text translation machine system (candidate) with translations obtained from humans (reference) [15]. The main task of BLEU is to compare n-grams of candidates with n-grams of references and count the number of words that appear. The more words that appear, the better the translation itself. The formula is [16]:

$$
\begin{aligned}
& B P_{B L U E}=f(x)=\left\{\begin{array}{cl}
1, & \text { if } c>r \\
e^{(1-r / c)}, & \text { if } c \leq r
\end{array}\right.
\end{aligned}
$$

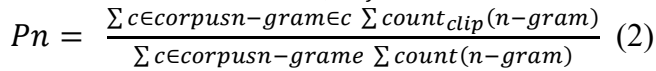

$$
\begin{aligned}
& B L U E=B P_{B L U E} \cdot e^{\sum_{n-1}^{N} w_{n} \log P_{n}}
\end{aligned}
$$

Information:

$\mathrm{BP}=$ brevity penalty

$\mathrm{C}=$ number of words from automatic translation

$\mathrm{R}=$ number of references

$\mathrm{Pn}=$ Modified precision score

$\mathrm{Wn}=1 / \mathrm{N}(\mathrm{N}$ for BLUE which is 4$)$

$\mathrm{Pm}=$ The number of $\mathrm{n}$-grams translated by reference divided by the number of $n$-grams translated.

\subsection{Steps of Research}

The following is a research design on a statistical translation machine from Muna Language to Indonesian which will be used in this final project using statistical methods where the method has several processes in figure 2 , namely as follows. 


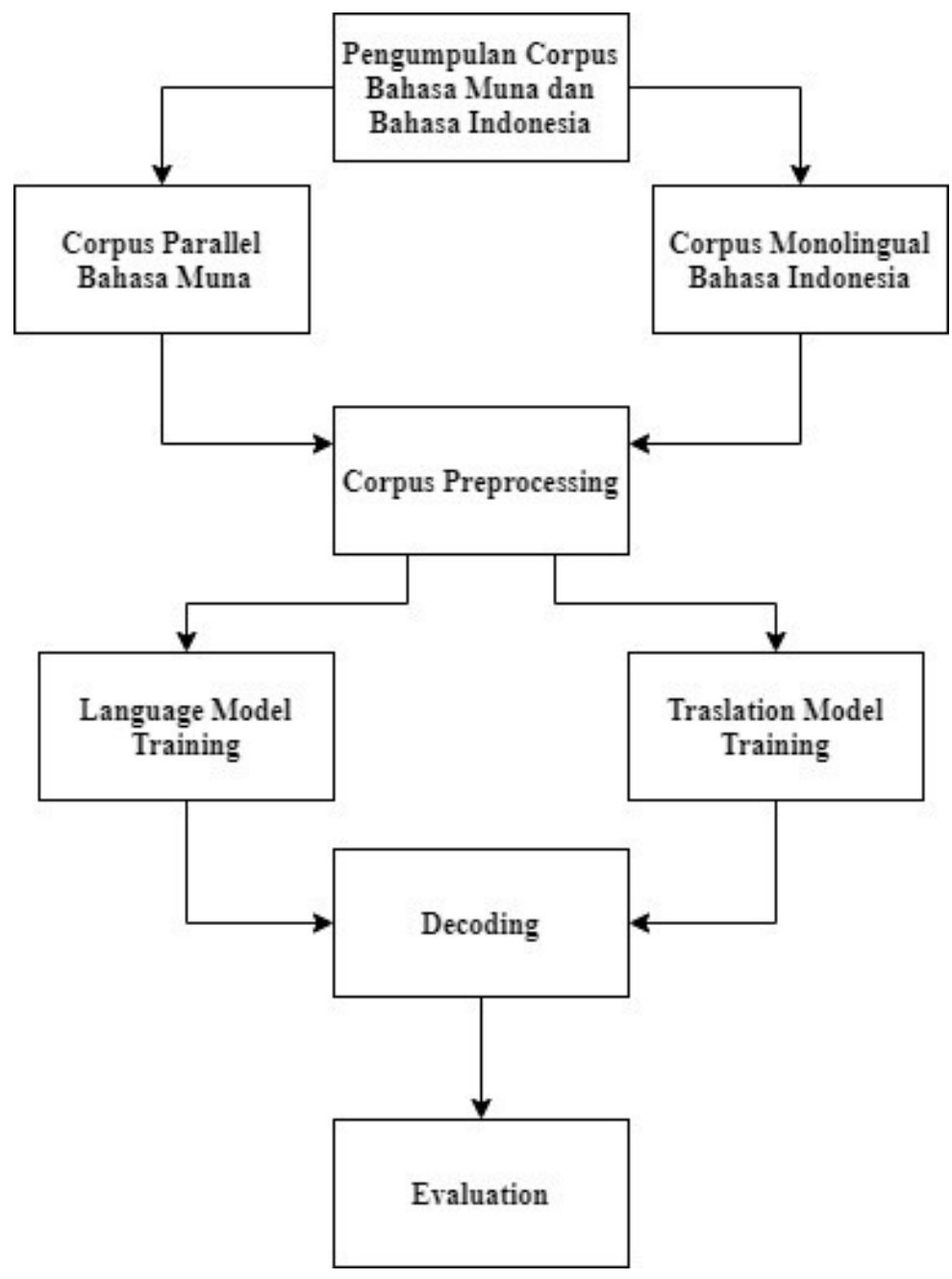

Figure 2 Architecture of The Moses Statistical Machine Translator Muna Language Into Indonesian

\section{2.1 Parallel Corpus and Monolingual Corpus}

To making this paper, the data needed to make a statistical translation machine are parallel corpus and monolingual corpus. The source taken for the parallel corpus is a book entitled Folklore of Buton and Muna in Southeast Sulawesi by Abd. Rasyid and monolingual corpus are taken from schoolnesia.com. For the parallel corpus, 1300 lines of Muna and Indonesian sentences are used, while for the monolingual corpus, 1351 lines of Indonesian sentences will be used.

\section{2.2 Corpus Prepocessing}

This stage of corpus preprocessing is used to prepare a corpus, where parallel corpus and monolingual corpus will be processed using a tool called Moses' decoder. The Moses decoder is used to train parallel corpus and monolingual corpus into translation and language models. The next steps to be carried out are tokenization, true case and cleaning. 
Tokenization is a process to give space between words, including spacing between words and existing punctuation marks. Examples of tokenization include the following: Input Sentence $=$ Omoafa hintu ana, kaasi.

Tokenization result $=$

- Omoafa hintu ana

- kaasi

The following is a script to tokenize:

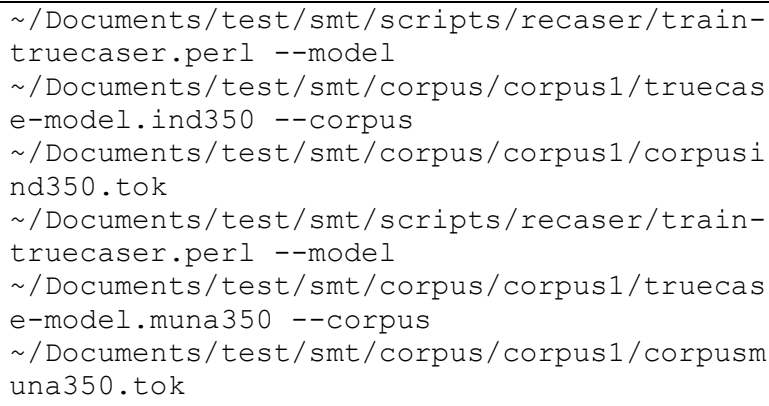

Truecase is the process of changing upper/lowercase letters with the most probable form between the two which aims to convert the prefix of each sentence according to the most probable place. The following is a script to perform Truecase:

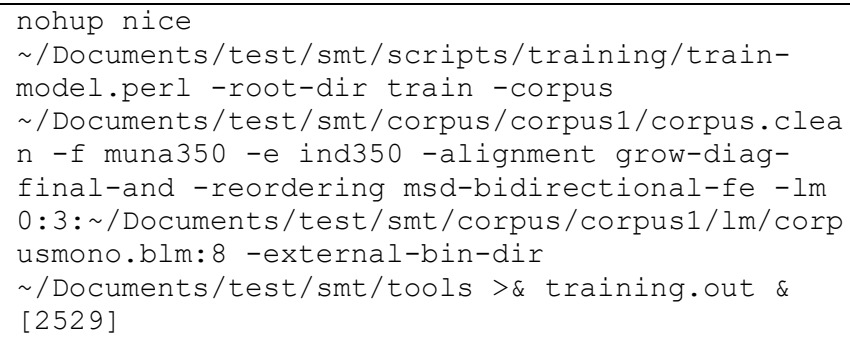

Cleaning is the process of removing empty spaces (excess white space) and also serves to remove misaligned sentences.

\section{2.3 Language Model Training and Traslation Model Training}

Language Model training is a language model training that will be used to ensure that the translation results include fluent sentences and get a model from the target language, namely Indonesian. in language testing, the language model that will be used is SRILM (SRI Language Modeling). SRILM is used for n-gram-based modeling, while translation model training is used to apply sentence alignment to parallel corpus. The alignment results are used to form a phrase table and the process to be executed using the GIZA++ tools. Here is the script from the training: 


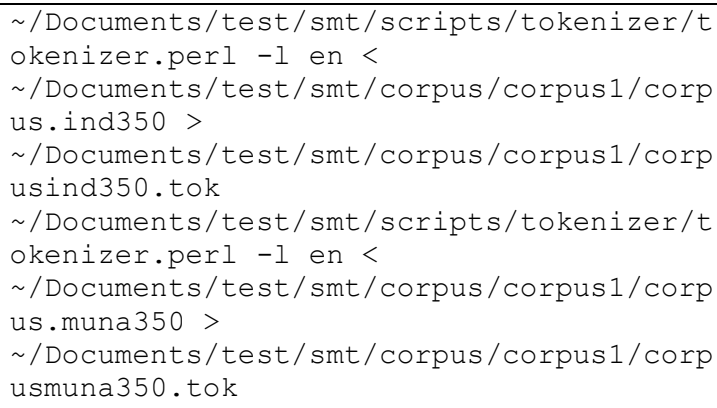

\section{2.4 Decoding}

Decoding is testing on machine translation, where the input sentence will be translated using the translation model and language model. The main process of decoding is to find the target language text that has the greatest probability of being translated as input sentences. The decoding process will use the Moses decoder. In the decoding process, it will translate an input sentence from the source language, namely the Muna language. Then the input sentence/source language will be processed using a mouse decoder and produce a target language sentence, namely Indonesian. The following script from Decoding is executed:

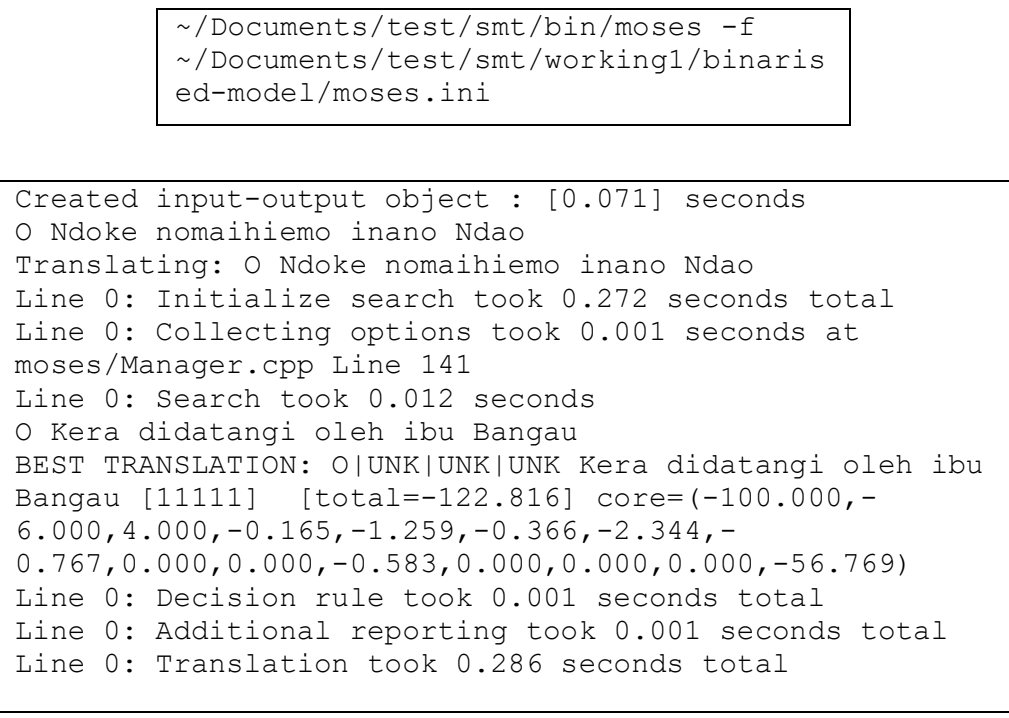

\section{2.5 Evaluation}

Evaluation is the last stage in the statistical translation machine from Muna to Indonesian using BLEU (Bilingual Evaluation Understudy). The following script results from the evaluation using BLEU from machine 1: 


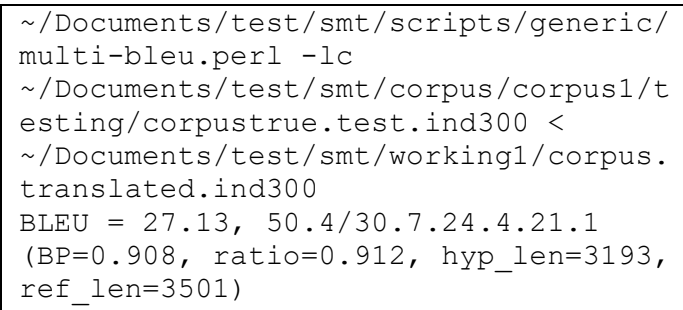

The scenarios that will be carried out in this experiment are divided into two scenarios. Scenario 1 is testing on the parallel corpus (training) which is tested using the available sentence lines and these sentence lines will be added to each experiment, while the rest of the sentence lines that are owned will be used in the parallel corpus (testing). The first experiment used 350 lines of parallel sentences (training) in Muna and Indonesian, the second experiment added 350 lines of Muna and Indonesian sentences so that the corpus parallel (training) became 700 lines

of Muna and Indonesian sentences, and the third experiment Added 350 lines of Muna and Indonesian sentences from the second experiment so that the corpus parallel (training) became 1050 lines of Muna and Indonesian sentences. The number of parallel corpus (testing) that will be used in scenario 1 is 300 lines of sentences in Muna and Indonesian. The number of monolingual corpus that will be used in scenario 1 is 1027 lines of Indonesian sentences.

In scenario 2, three times the monolingual corpus was tested with the condition that the best accuracy results from scenario 1. In the fourth experiment, the number of monolingual corpus was reduced to 342 lines of Indonesian sentences, the fifth experiment was to increase the number of monolingual corpus by 342 lines of English sentences. Indonesia so that the number of monolingual corpus becomes 684 lines of Indonesian sentences, while the sixth experiment was carried out to increase the number of monolingual corpus by 1351 lines of Indonesian sentences. The corpus parallel (training) used is still the same, with 300 lines of sentences in Muna and Indonesian.

The purpose of the two test scenarios is to get the best BLUE value from the six experiments that have been carried out. 


\section{RESULTS AND DISCUSSION}

The following are the results of scenario 1 testing carried out by the Muna language statistical translator machine into Indonesian which can be seen in table 1:

Table 1 The Result from score BLEU skenario 1

\begin{tabular}{|l|c|c|c|}
\hline & $\begin{array}{c}\text { Konfigurasi } \\
\text { Mesin 1 }\end{array}$ & $\begin{array}{c}\text { Konfigurasi } \\
\text { Mesin 2 }\end{array}$ & $\begin{array}{c}\text { Konfigurasi } \\
\text { Mesin 3 }\end{array}$ \\
\hline $\begin{array}{l}\text { Number of Parallel Corpus } \\
\text { (Training) }\end{array}$ & 350 & 700 & 1050 \\
\hline $\begin{array}{l}\text { Number of Monolingual } \\
\text { Corpus }\end{array}$ & 1027 & 1027 & 1027 \\
\hline $\begin{array}{l}\text { Number of Parallel Corpus } \\
\text { (Testing) }\end{array}$ & 300 & 300 & 300 \\
\hline Score result (BLEU) & $27,13 \%$ & $27,31 \%$ & $28,68 \%$ \\
\hline Percentage Increase & & $+0,18 \%$ & $+1,37 \%$ \\
\hline
\end{tabular}

Table 1 shows the total of statistical machine translation research from Muna to Indonesian where machine configuration 1 gets a BLEU value of $27.13 \%$, machine configuration 2 gets a BLEU value of $27.31 \%$, machine configuration 3 gets a BLEU value of $28.68 \%$. From the three BLEU values, it can be seen that the three engines experienced an increase as follows: engine configuration 1 and engine configuration 2 increased by $0.18 \%$, engine configuration 2 and engine configuration 3 increased by $1.37 \%$. Then from the 3 statistical translation machines from Muna to Indonesian, one machine translation configuration with the best BLEU value was taken based on the three machine translation configurations, namely machine configuration 3 . Then, it was tested again with a different monolingual corpus division to increase the results of machine translator configuration analysis. The following table 2 shows the results of scenario 2 to show the results of the test.

Table 2 The Result from Score BLEU Skenario 2

\begin{tabular}{|l|c|c|c|}
\hline & $\begin{array}{c}\text { Konfigurasi } \\
\text { Mesin 4 }\end{array}$ & $\begin{array}{c}\text { Konfigurasi } \\
\text { Mesin 5 }\end{array}$ & $\begin{array}{c}\text { Konfigurasi } \\
\text { Mesin 6 }\end{array}$ \\
\hline $\begin{array}{l}\text { Number of Parallel Corpus } \\
\text { (Training) }\end{array}$ & 1050 & 1050 & 1050 \\
\hline $\begin{array}{l}\text { Number of Monolingual } \\
\text { Corpus }\end{array}$ & 342 & 684 & 1351 \\
\hline $\begin{array}{l}\text { Number of Parallel Corpus } \\
\text { (Testing) }\end{array}$ & 300 & 300 & 300 \\
\hline Score result (BLEU) & $27,81 \%$ & $28,40 \%$ & $29,83 \%$ \\
\hline Percentage Increase & & $+0,51 \%$ & $+1,43 \%$ \\
\hline
\end{tabular}

Table 2 contains the total of monolingual corpus division studies. Engine configuration 4 gets a BLEU value of $27.81 \%$, engine configuration 5 gets a BLEU value of $28.40 \%$, engine configuration 6 gets a BLEU value of $29.83 \%$. From the division of the monolingual body, it can be seen that there is an increase. Engine configuration 1 and engine configuration 2 
increased by $0.51 \%$, then engine configuration 2 and engine configuration 3 increased by $1.43 \%$.

Then, this is the result from implementation Muna Language statistical translator engine to Indonesian based on website. There is an initial display which had to make:

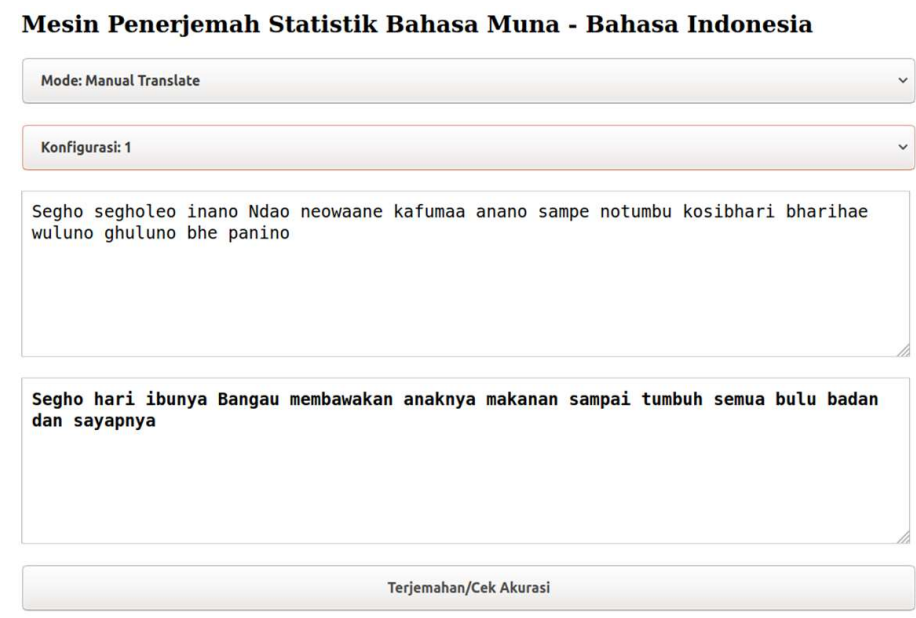

Figure 3 Initial Display to Manual Translate Mode

In Figure 3, there is an initial display of the Muna Language statistical translator engine to Indonesian in Manual Translate Mode which has the following functions.

1. Select the machine translator configuration type.

2. Inputting words/sentences in Muna Language.

3. Translate words/sentences into Indonesian.

Mesin Penerjemah Statistik Bahasa Muna - Bahasa Indonesia

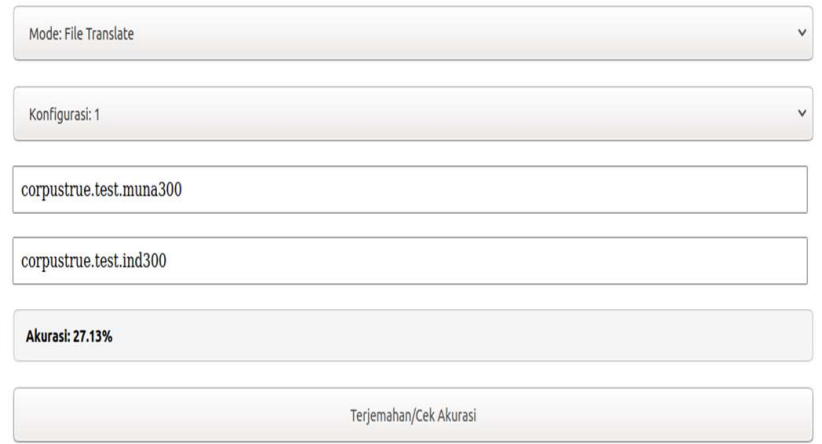

Figure 4 Initial Display to File Translate Mode

In Figure 4, it has several functions as follows.

1. Select the machine translator configuration type.

2. Upload a Muna language file and then translate it into Indonesian.

3. Uploading an Indonesian reference file

4. Compare both source and reference files.

5. View the accuracy results to get the BLEU value 
The results of the statistical translation machine from Muna to Indonesian using 350 lines of corpus training and 1027 lines of monolingual corpos produce a BLEU value of $27.13 \%$, the results of the translation using corpus training are 700 lines of sentences and corpos monolingual are 1027 lines of sentences. produces a BLEU value of $27.31 \%$ and for translation results using corpus training as many as 1050 lines of sentences and corpos monolingual as many as 1027 lines of sentences produces a BLEU value of $28.68 \%$.

The increase in the BLEU value in machine configuration 1 to machine configuration 2 with a comparison of corpus training of 350 lines of sentences increased by $0.18 \%$, after that from machine configuration 2 to machine configuration 3 with a comparison of corpus training of 350 lines of sentences an increase of $1.37 \%$. which can be seen from the comparison of some of the sentences in the following cases which are marked with a description of the color of the sentence, namely green for sentences that are successfully translated while red for sentences that fail to be translated:

\section{Example of Case 1}

Input Sentence: Posora soraha metingkeno wughuno kalambe Satarina dopobha pobhalogho lagu bhe bidadarihi pipituno doforatogho anagha ne moghaneno kalambe Satarina.

Target Language: Tetangga yang mendengar suara Putri Satarina berbalas-balasan lagu dengan bidadari yang tujuh orang itu menyampaikan hal itu kepada suami Putri Satarina.

Konfigurasi Mesin 1: Posora soraha metingkeno suara Putri Satarina berbalas-balasan lagu dan bidadari yang tujuh orang itu menyampaikan hal itu kepada suami Putri Satarina

Konfigurasi Mesin 2: Posora soraha metingkeno suara Putri Satarina berbalas-balasan lagu dan bidadari menyampaikan hal itu kepada suaminya Putri Satarina

Konfigurasi Mesin 3: Posora soraha metingkeno suara putri Satarina berbalas-balasan lagu dengan bidadari yang tujuh orang itu menyampaikan hal itu kepada suaminya Putri Satarina

Konfigurasi Mesin 4: Posora soraha metinkeno suara gadis Satarina berbalas-balasan lagu dengan bidadari yang tujuh orang itu menyampaikan hal itu kepada suami Putri Satarina

Konfigurasi Mesin 5: Posora soraha metingkeno suara gadis Satarina berbalas-balasan lagu dan bidadari tujuh orang itu menyampaikan hal itu kepada suaminya gadis Satarina

Konfigurasi Mesin 6: Posora soraha metingkeno suara Putri Satarina berbalas-balasan lagu dengan bidadari yang tujuh orang itu menyampaikan hal itu kepada suami Putri Satarina.

\section{Example of Case 2}

Input Sentence: Nosuli kaawu ghuluno peda da daano dohoromo Ndao bhe inano dosuli we kaelatehando indefieini

Target Language: Setelah keadaan tubuhnya pulih seperti sediakala terbanglah Bangau bersama-sama ibunya kembali ke tempat tinggalnya yang lama.

Konfigurasi Mesin 1: Setelah badan seperti sediakala terbanglah Bangau bersama-sama ibunya kembali ke tempat tinggalnya yang lama.

Konfigurasi Mesin 2: Setelah badan seperti sediakala terbanglah Bangau bersama-sama ibunya kembali ke tempat tinggalnya yang lama.

Konfigurasi Mesin 3: Setelah keadaan tubuhnya pulih seperti sediakala terbanglah Bangau bersama-sama ibunya kembali ke tempat tinggalnya yang lama.

Konfigurasi Mesin 4: Setelah badannya seperti sediakala terbanglah Bangau dan ibunya kembali di tempat tinggalnya yang lama.

Konfigurasi Mesin 5: Setelah tubuhnya pulih seperti sediakala terbanglah Bangau dan ibunya kembali ke tempat tinggalnya yang lama.

Konfigurasi Mesin 6: Setelah tubuhnya pulih seperti sediakala terbanglah Bangau bersama ibunya kembali ke tempat tinggalnya yang lama. 
Example of Case 3

Input Sentence: Gurudha nolea sepaliha lalono nee Ndoke, noafa o Ndoke ini sabdea noakali kanaugho.

Target Language: Rajawali merasa sakit hati pada Kera, mengapa Kera ini selalu menipuku.

Konfigurasi Mesin 1: Rajawali merasa sakit hati di Ndoke, mengapa Kera ini selalu noakali kanaugho.

Konfigurasi Mesin 2: Rajawali merasa sakit hati di Ndoke, mengapa Kera ini selalu noakali kanaugho.

Konfigurasi Mesin 3: Rajawali merasa sakit hati pada Ndoke, mengapa Kera ini selalu noakali kanaugho.

Konfigurasi Mesin 4: Rajawali geram sekali hati di Ndoke, mengapa Kera ini selalu noakali kanaugho.

Konfigurasi Mesin 5: Rajawali merasa sakit hati di Ndoke, mengapa Kera ini selalu noakali kanaugho.

Konfigurasi Mesin 6: Rajawali merasa sakit hati pada Ndoke, mengapa Kera ini selalu noakali kanaugho.

\section{CONCLUSION}

From several tests and analyzes that have been carried out, it can be concluded that statistical machine translation can be implemented to translate Muna into Indonesian. Corpus training on statistical translation machines greatly affects the results of the BLEU score, the more corpus training there is, the better the BLEU score will be. Meanwhile, the corpus has quite an influence on the BLEU value on the Muna statistical translation machine into Indonesian. The best accuracy value is found in machine configuration 6 with 1050 lines of corpus training, 300 lines of corpus testing and 1350 lines of monolingual corpus with a BLEU value of $29.83 \%$.

\section{SUGGESTION}

Based on the results of the analysis in this study, further research needs to be done in building a statistical translation machine because the accuracy results obtained have not been able to reach $50 \%$ and also the parallel corpus collected is still small. It is hoped that further research can collect quite a lot of parallel corpuses and can change the accuracy of the statistical translation machine. 


\section{REFERENCES}

[1] R. van den Berg, 1989. A Grammar of the Muna Language, Land- en Volkenkunde: Verhandelingen van het Koninklijk Instituut voor Taal,

[2] R. van den Berg, 2003. "The place of Tukang Besi and the Muna-Buton languages," Austronesian historical phonology, pp. 87-144,

[3] H. Sunjani, 2020. "Peningkatan Akurasi Mesin Penerjemah Bahasa Inggris-Indonesia Dengan Memaksimalkan Kualitas dan Kuantitas Korpus Paralel," Jurnal Teknologi Informasi dan Ilmu Komputer (JTIIK),

[4] T. B. A. B. S. H. Rizky Aditya Nugroho, 2015. "Penerjemah Bahasa Indonesia dan Bahasa Jawa Menggunakan Metode Statistik Berbasis Frasa," SENTIKA,

[5] H. S. N. S. Della Widya Ningtyas, 2018."Pengunaan Pivot Language pada Mesin Penerjemah Statistik Bahasa Inggris ke Bahasa Melayu Sambas, " Jepin,

[6] D. H. W. A. P. Y. S. Arie Ardiyanti Suryani, 2015"Experiment on a Phrase-Based Statistical Machine Translation," in 2015 International Conference on Information Technology Systems and Innovation (ICITSI), Bandung - Bali,.

[7] H. I., 2014"Uji Akurasi Mesin Penerjemah Statistik Bahasa Indonesia ke Bahasa Melayu Sambas," Justin,.

[8] H. S. R. D. N. Try Wahyudinata, 2016"Implementasi Mesin Penerjemah Statistik Berbasis Android Dengan Moses Decoder," Jurnal Sistem dan Teknologi Informasi (JUSTIN) Vol. 3, No. 1.

[9] S. H., 2015. "Analysis of Extend Word Similarity Clustering based Algorithm on Cognate Language," Gujarat: ESRSA Publications Pvt, Ltd,

[10] S. H., 2014. "Strategi Memperbaiki Kualitas Korpus Untuk Meningkatkan Kualitas Mesin Penerjemah Statistik," Seminar Nasional Teknologi Informasi,

[11] H. M, 2016. "Tuning Quality Untuk Uji Akurasi Mesin Penerjemah Statistik (MPS) Bahasa Indonesia - Bahasa Dayak Kanayatn," Jepin,

[12] H. S. N. S. Yosep Jarob R, 2016. "Uji Akurasi Penerjemahan Bahasa Indonesia - Dayak Taman dengan Penandaan Kata Dasar dan Imbuhan," Jurnal Edukasi dan Penelitian Informatika (JEPIN),

[13] H. S. R. D. N. Khamsah Akbar, 2018. "Pengaruh Domain Teks Pada Korpus Terhadap Akurasi Mesin Penerjemah Statistik," Jurnal Sistem dan Teknologi Informasi (JUSTIN),

Agigi, et., al [Statistical Machine Translation Muna To Indonesia Language] 
[14] W. H, 2007. "Pivot Language Approach for Phrase-Based Statistical Machine Traslation," Proceedings 0g 45th Annuak Meeting of the Association for Computational Linguistics, Haifeng,

[15] S. R. T. W. a. W.-J. Z. Kishore Papineni, 2002. "BLEU: a Method for Automatic Evaluation of Machine Translation," in Proceedings of the 40th Annual Meeting of the Association for Computational Linguistics (ACL), Philadelphia, July 2002, pp. 311-318., Philadelphia,

[16] T. McEnery, "Corpus-Based Language Studies," An Advanced Resource, 2006. 